\title{
Assessment of Psychosocial Risks At WORK
}

\author{
PaCAiova, H. \& BALAZIKOVA, M.
}

Abstract:In community is trend to be useful, be successful, to manage different situations, to pass all difficulties and adjust with requirements and demands of certain tasks. Work capacity of every man is not unlimited and overrun of this capacity could have negative consequences to health and performance. In different cases and conditions of work life can appear different events which have influence to psychic balance and generate stress.

The article describes the method of assessment of psychosocial risk matrix using the newly created risk by identifying areas of stress, ie. stressors and their consequences are evaluated in three impacts :

- Impact on the safety (human error / injury),

- Health hazards,

- Decrease of availability.

Key words: risks, hazard, stress, safety, health
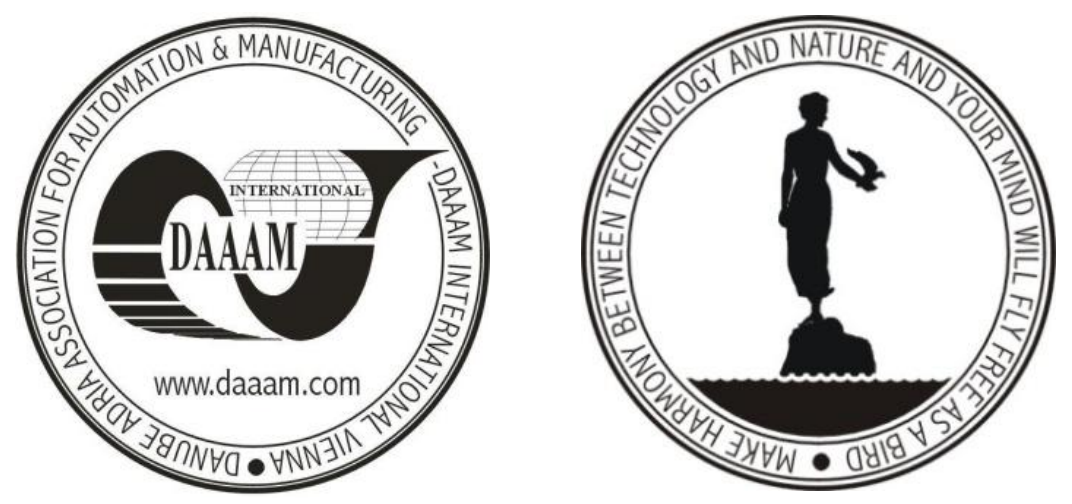

Authors' data: prof. Ing. $\mathrm{PhD}$, Pacaiova, $\mathrm{H}$ [ana]; Ing. PhD. Balazikova, M[ichaela], Technical University of Kosice, Faculty of Engineering, Department of Safety and Quality, Letná 9, 04200, Kosice, Slovakia, michaela.balazikova@tuke.sk, pacof@centrum.sk

This Publication has to be referred as: Pacaiova, H[ana] \& Balazikova, M[ichaela] (2010). Assessment of Psychosocial Risks at Work, Chapter 33 in DAAAM International Scientific Book 2010, pp. 347-356, Published by DAAAM International, ISBN 978-3-901509-74-2, ISSN 1726-9687, Vienna, Austria DOI: $10.2507 /$ daaam.scibook.2010.33 


\section{Introduction}

The world of work is fundamentally changing, bringing new challenges to the health and safety of employees. These changes lead to new psychosocial risks. Such risks, which relate to the concept of allocation, organization and management of work, as well as their economic and social context, result in increased stress levels, which can lead to serious deterioration of mental and physical health, increased injury and reduced effectiveness.

\section{Emerging psychosocial risks}

Research and studies show that emerging psychosocial OSH risks are often the result of technical or organizational changes. Important factors are also socioeconomic, demographic and political changes, including the current phenomenon globalization.

Research and studies show that most emerging psychosocial risks can be divided into areas:

1. new forms of employment contracts and job insecurity,

2. aging workforce,

3. work intensification,

4. high emotional demands at work,

5. imbalance in work and personal life.

Work stress risk assessment includes the same basic principles and processes that apply to other workplace hazards. Involvement of employees and their representatives into this process is a key factor of success. Employees should know what causes stress, which groups are suffering and what can be done for remedy (OHSA - European Agency, 2007).

\section{Psychosocial risk assessment algorithm}

The following section describes the method for assessing psychosocial risk using the newly created risk matrix with identified areas of stress, i.e. stressors and their consequences, which are evaluated in three impact areas:

○ Impact on security (human error/injury),

- Health hazards ,

○ Reduction of work effectiveness.

Work effectiveness of the employee $\left(\mathrm{P}_{\mathrm{h}}\right)$ in the process of stress elements action consists of three weight factors:

where:

$$
P_{h}=V_{k} \times K_{v} \times E_{x}
$$

$\mathrm{V}_{\mathrm{k}}$ - employee performance,

$\mathrm{K}_{\mathrm{v}}$ - quality of work performed,

$\mathrm{E}_{\mathrm{x}}$ - time use. 
In the Fig. 1, an algorithm is designed to assess psychosocial risks causing stress to employees at work and in Fig. 2 (Šolc, 2009) is a division of stressors into two main categories - physical and psychosocial.

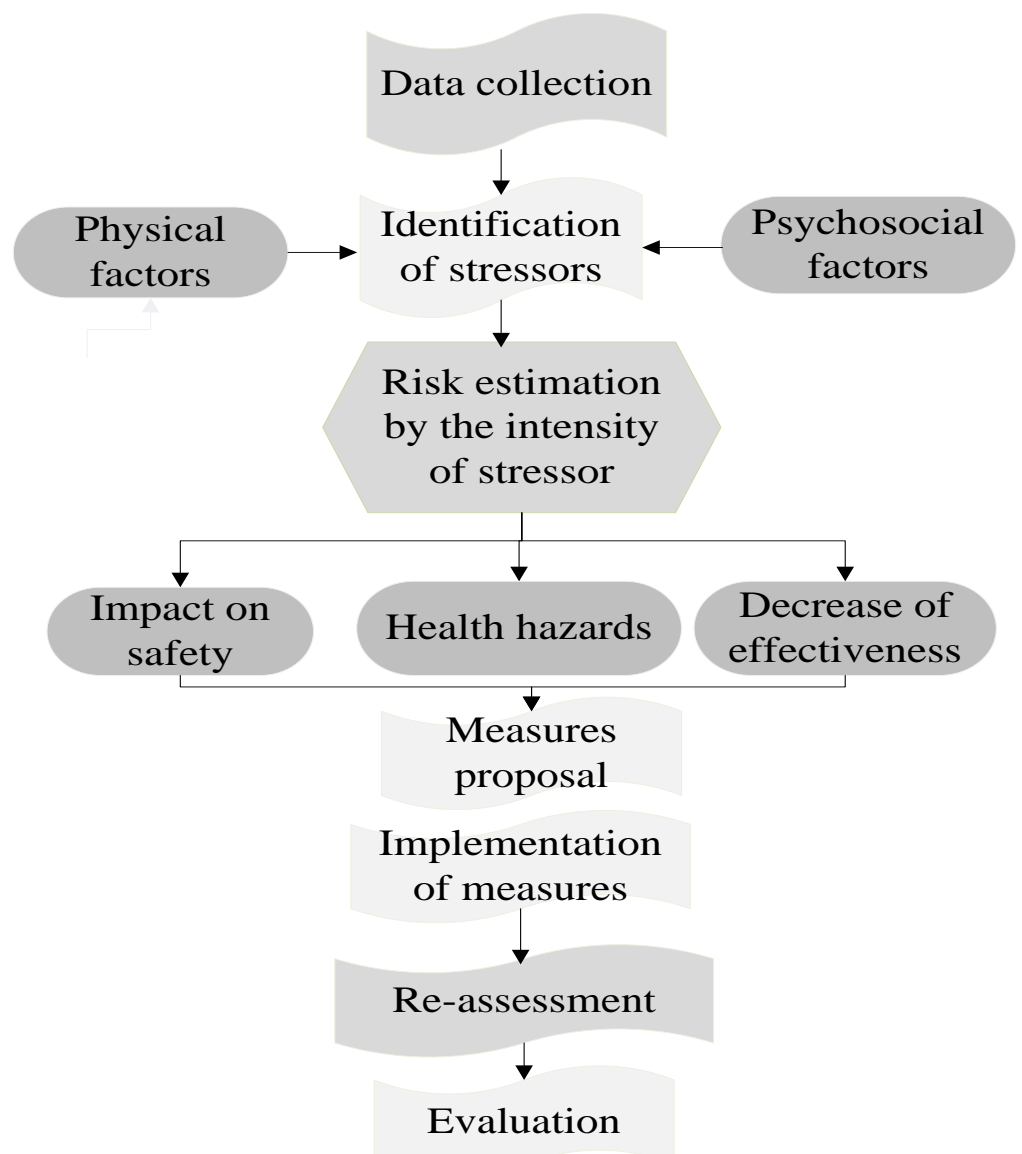

Fig. 1. Proposed algorithm for the assessment of psychosocial risk

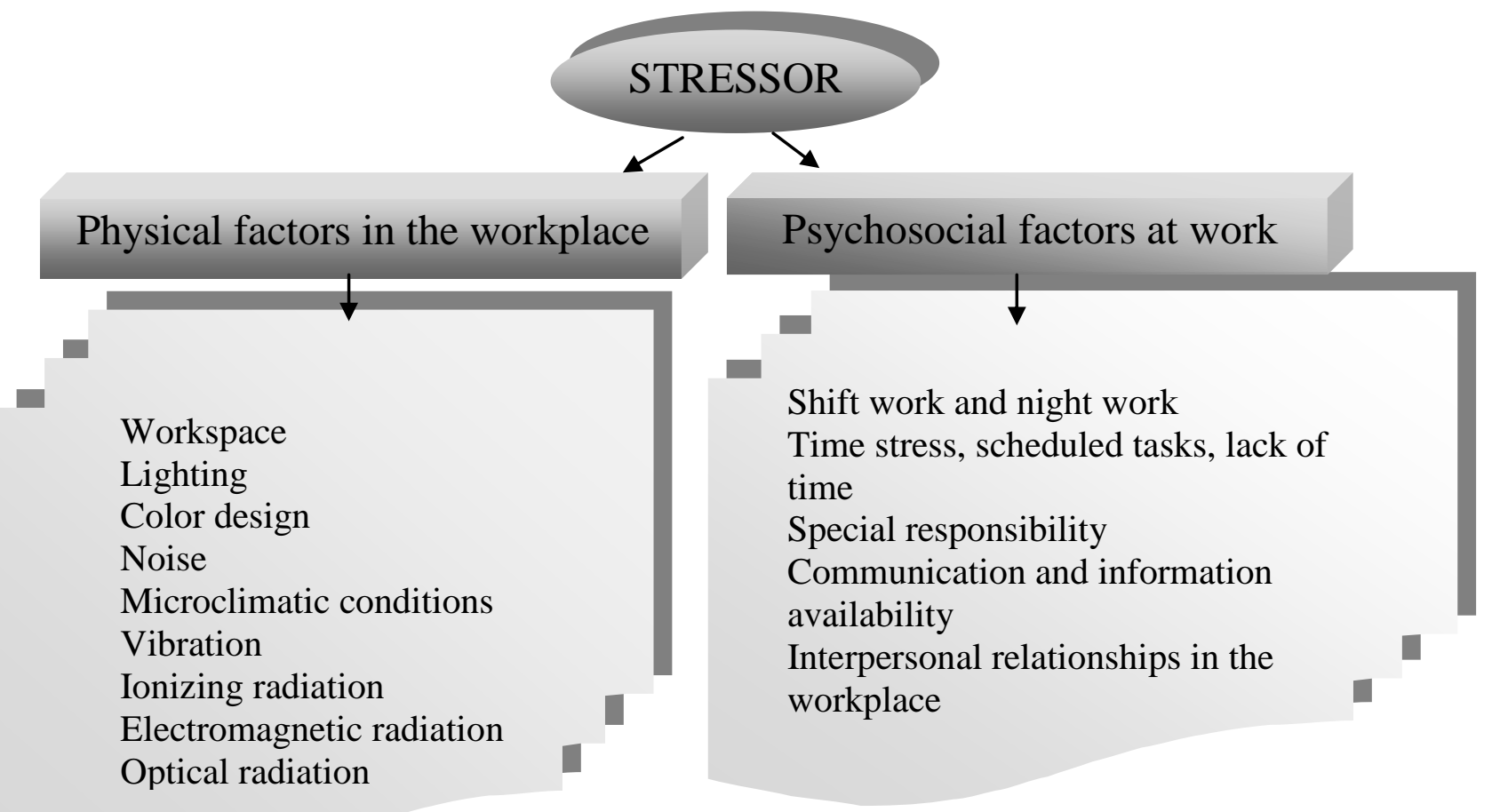

Fig. 2. Distribution of stressors affecting the psychological burden 


\subsection{Preparation - data collection}

Objective information can be obtained from the technological procedures and manuals, the measurement of harmful or dangerous and nuisance factors at work, records of work accidents and occupational diseases.

Subjective information to identify the source of stress are data from observation of the work environment, observation of work in the workplace, interviews with staff and observation of external factors that may affect the workplace.

\subsection{Identification of dangers and hazards in the workplace}

Evaluating selected system, it is necessary to identify only those properties which may give rise to negative phenomena in the form of threats to health, increased injury and reduced effectiveness (Kul'havý, 2005).

To identify risks and hazards in the workplace, the checklist in Tab. 1 can be used.

\begin{tabular}{|c|c|c|c|c|}
\hline No. & HAZARD: Stress at work & Yes & $\begin{array}{l}\text { Some- } \\
\text { times }\end{array}$ & No \\
\hline I. & Work Environment & \multicolumn{3}{|c|}{ Physical factors } \\
\hline 1. & $\begin{array}{l}\text { Is ergonomic equipment of working environment } \\
\text { unsatisfactory? }\end{array}$ & $\square$ & $\square$ & $\square$ \\
\hline 2. & $\begin{array}{l}\text { Does spatial layout of the workplace not meet the needs of } \\
\text { employees and performed work? }\end{array}$ & $\square$ & $\square$ & $\square$ \\
\hline 3. & $\begin{array}{l}\text { Are there physical hazards (noise, excessive heat, poor } \\
\text { lighting, humidity) in the workplace? }\end{array}$ & $\square$ & $\square$ & $\square$ \\
\hline 4. & Are there burdensome substances? & $\square$ & $\square$ & $\square$ \\
\hline 5. & $\begin{array}{l}\text { Are working implements used by employees at work not } \\
\text { sufficient? }\end{array}$ & $\square$ & $\square$ & $\square$ \\
\hline II. & Job demands & \multicolumn{3}{|c|}{$\begin{array}{l}\text { Psychosocial } \\
\text { factors }\end{array}$} \\
\hline 6. & Is work physically demanding? & $\square$ & $\square$ & $\square$ \\
\hline 7. & $\begin{array}{l}\text { Is there an imbalance between physical and mental demands } \\
\text { of work and employees capability? }\end{array}$ & $\square$ & $\square$ & $\square$ \\
\hline 8. & Is there mental work load? & $\square$ & $\square$ & $\square$ \\
\hline 9. & Is there emotional burden? & $\square$ & $\square$ & $\square$ \\
\hline 10. & Is work monotonous? & $\square$ & $\square$ & $\square$ \\
\hline 11. & Do short cyclic activities occur in the workplace? & $\square$ & $\square$ & $\square$ \\
\hline 12. & Are personal performance standards too high? & $\square$ & $\square$ & $\square$ \\
\hline 13. & Are employees socially isolated in the course of their work? & $\square$ & $\square$ & $\square$ \\
\hline III. & Organization of work & \multicolumn{3}{|c|}{$\begin{array}{l}\text { Psychosocial } \\
\text { factors }\end{array}$} \\
\hline 14. & Is alternation of activity and rest phases insufficient? & $\square$ & $\square$ & $\square$ \\
\hline 15. & Is there lack of work equipment? & $\square$ & $\square$ & $\square$ \\
\hline 16. & Is information on new tasks provided to employees well in & $\square$ & $\square$ & $\square$ \\
\hline
\end{tabular}




\begin{tabular}{|c|c|c|c|c|}
\hline & advance before changes apply? & & & \\
\hline 17. & $\begin{array}{l}\text { Is there lack of information about performed work and } \\
\text { working procedures? }\end{array}$ & $\square$ & $\square$ & $\square$ \\
\hline 18. & $\begin{array}{l}\text { Is there too much information, so employees can't even } \\
\text { remember it all? }\end{array}$ & $\square$ & $\square$ & $\square$ \\
\hline 19. & $\begin{array}{l}\text { Do employees often not know what are their roles and } \\
\text { responsibilities? }\end{array}$ & $\square$ & $\square$ & $\square$ \\
\hline 20. & $\begin{array}{l}\text { Can employees influence the methods by which they perform } \\
\text { their work tasks? }\end{array}$ & $\square$ & $\square$ & $\square$ \\
\hline 21. & Do employees usually work in a fast pace? & $\square$ & $\square$ & $\square$ \\
\hline 22. & Are there contradictory requirements on employees? & $\square$ & $\square$ & $\square$ \\
\hline 23. & Is the work specification obscure and incomprehensible? & $\square$ & $\square$ & $\square$ \\
\hline 24. & Is the work unpredictable and defiant to plan? & $\square$ & $\square$ & $\square$ \\
\hline 25. & Are employees in their work often disturbed and bothered? & $\square$ & $\square$ & $\square$ \\
\hline 26. & $\begin{array}{l}\text { Do employees have the opportunity to plan their work, make } \\
\text { decisions and take responsibility? }\end{array}$ & $\square$ & $\square$ & $\square$ \\
\hline 27. & Is the shift schedule prepared in advance? & $\square$ & $\square$ & $\square$ \\
\hline 28. & Must employees often work at night? & $\square$ & $\square$ & $\square$ \\
\hline 29. & Must employees usually work overtime? & $\square$ & $\square$ & $\square$ \\
\hline 30. & Are working hours fixed? & $\square$ & $\square$ & $\square$ \\
\hline 31. & Do employees experience overload from volume of work? & $\square$ & $\square$ & $\square$ \\
\hline 32. & Do employees usually work under high time pressure? & $\square$ & $\square$ & $\square$ \\
\hline 33. & Is the workload usually very high? & $\square$ & $\square$ & $\square$ \\
\hline 34. & Does rush work occur often in the workplace? & $\square$ & $\square$ & $\square$ \\
\hline 35. & Can employees influence their job description? & $\square$ & $\square$ & $\square$ \\
\hline 36. & Are employees trained for their new work roles? & $\square$ & $\square$ & $\square$ \\
\hline IV. & Orientation and safety & \multicolumn{3}{|c|}{$\begin{array}{l}\text { Psychosocial } \\
\text { factors }\end{array}$} \\
\hline 37. & Is there fear of losing the job? & $\square$ & $\square$ & $\square$ \\
\hline 38. & Is there feedback on work performance of employees? & $\square$ & $\square$ & $\square$ \\
\hline 39. & Is there lack of information on safety in the workplace? & $\square$ & $\square$ & $\square$ \\
\hline 40. & Are employees poorly motivated? & $\square$ & $\square$ & $\square$ \\
\hline 41. & Is there an opportunity for further development and learning? & $\square$ & $\square$ & $\square$ \\
\hline 42. & Is employees allocation unclear? & $\square$ & $\square$ & $\square$ \\
\hline 43. & Is information on the work tasks unclear? & $\square$ & $\square$ & $\square$ \\
\hline 44. & $\begin{array}{l}\text { Do employees meet the qualification requirements for the } \\
\text { work carried out? }\end{array}$ & $\square$ & $\square$ & $\square$ \\
\hline V. & Creative space & \multicolumn{3}{|c|}{$\begin{array}{l}\text { Psychosocial } \\
\text { factors }\end{array}$} \\
\hline 45. & Is wokplace lacking guard and control mechanisms? & $\square$ & $\square$ & $\square$ \\
\hline 46. & $\begin{array}{l}\text { Is there an opportunity for the employees to participate on the } \\
\text { management? }\end{array}$ & $\square$ & $\square$ & $\square$ \\
\hline
\end{tabular}


Pacaiova, H. \& Balazikova, M.: Assessment of Psychosocial Risks at Work

\begin{tabular}{|l|l|l|l|l|}
\hline 47. & Is there a possibility of creating new activities? & $\square$ & $\square$ & $\square$ \\
\hline 48. & Is pace of work imposed on the employees? & $\square$ & $\square$ & $\square$ \\
\hline VI. & Social climate & \multicolumn{2}{|c|}{$\begin{array}{l}\text { Psychosocial } \\
\text { factors }\end{array}$} \\
\hline 49. & Are there signs of discrimination in the workplace? & $\square$ & $\square$ & $\square$ \\
\hline 50. & Is there a bad climate in the company towards superiors? & $\square$ & $\square$ & $\square$ \\
\hline 51. & $\begin{array}{l}\text { Remain conflicting issues and problems between staff and } \\
\text { management unresolved? }\end{array}$ & $\square$ & $\square$ & $\square$ \\
\hline 52. & $\begin{array}{l}\text { Are there interpersonal conflicts or conflicts between groups } \\
\text { of employees? }\end{array}$ & $\square$ & $\square$ & $\square$ \\
\hline 53. & $\begin{array}{l}\text { Have employees the opportunity to address problems and } \\
\text { conflicts? }\end{array}$ & $\square$ & $\square$ & $\square$ \\
\hline 54. & Is there a support from colleagues or superiors? & $\square$ & $\square$ & $\square$ \\
\hline 55. & Is there a strong competition among employees? & $\square$ & $\square$ \\
\hline 56. & $\begin{array}{l}\text { Is cooperation among different groups of employees weak } \\
\text { (e.g. among individual organizational units)? }\end{array}$ & $\square$ & $\square$ & $\square$ \\
\hline 57. & Is the social climate in the workplace poor? & $\square$ & $\square$ & $\square$ \\
\hline 58. & $\begin{array}{l}\text { Do employees experience insufficient appreciation for their } \\
\text { work? }\end{array}$ & $\square$ & $\square$ & $\square$ \\
\hline 59. & Is there bullying and harassment? & $\square$ & $\square$ & $\square$ \\
\hline 60. & $\begin{array}{l}\text { Are employees exposed to the risk of violence from the public } \\
\text { (verbal abuse, threats, physical attacks)? }\end{array}$ & $\square$ & $\square$ \\
\hline
\end{tabular}

Tab. 1. Specific checklist for the risk of occupational stress (Sabolová, 2009)

This checklist can identify most of the hazards causing mental workload. Hazards are essentially stressors arising in work process. Answering individual questions, employees can choose one of the three options. To assess the effects of individual stressors on employee it is necessary to know whether the intensity of stressor occurrence is frequent or if it occurs only occasionally.

\subsection{Estimation of risks arising from hazards}

After identification of hazards the risk is assessed by determination of risk parameters for each individual hazard. The risk is derived by combination of the following parameters:

- severity of damage and its consequences,

- the probability of such damage, which is a function:

a) frequency and duration of exposure to hazard,

b) the likelihood of adverse events occurrence,

c) the technical capabilities and human capabilities to prevent or avoid risk.

The category 'probability of occurrence' of adverse mental workload reflects the intensity of stressors that cause mental workload. 
The category 'consequences' of the intensity of stressor reflects the severity of possible health damage, number of human error/injury and decrease of employees effectivity, Tab. 2.

The resulting risk matrix for mental workload assessment is in the Tab. 2 .

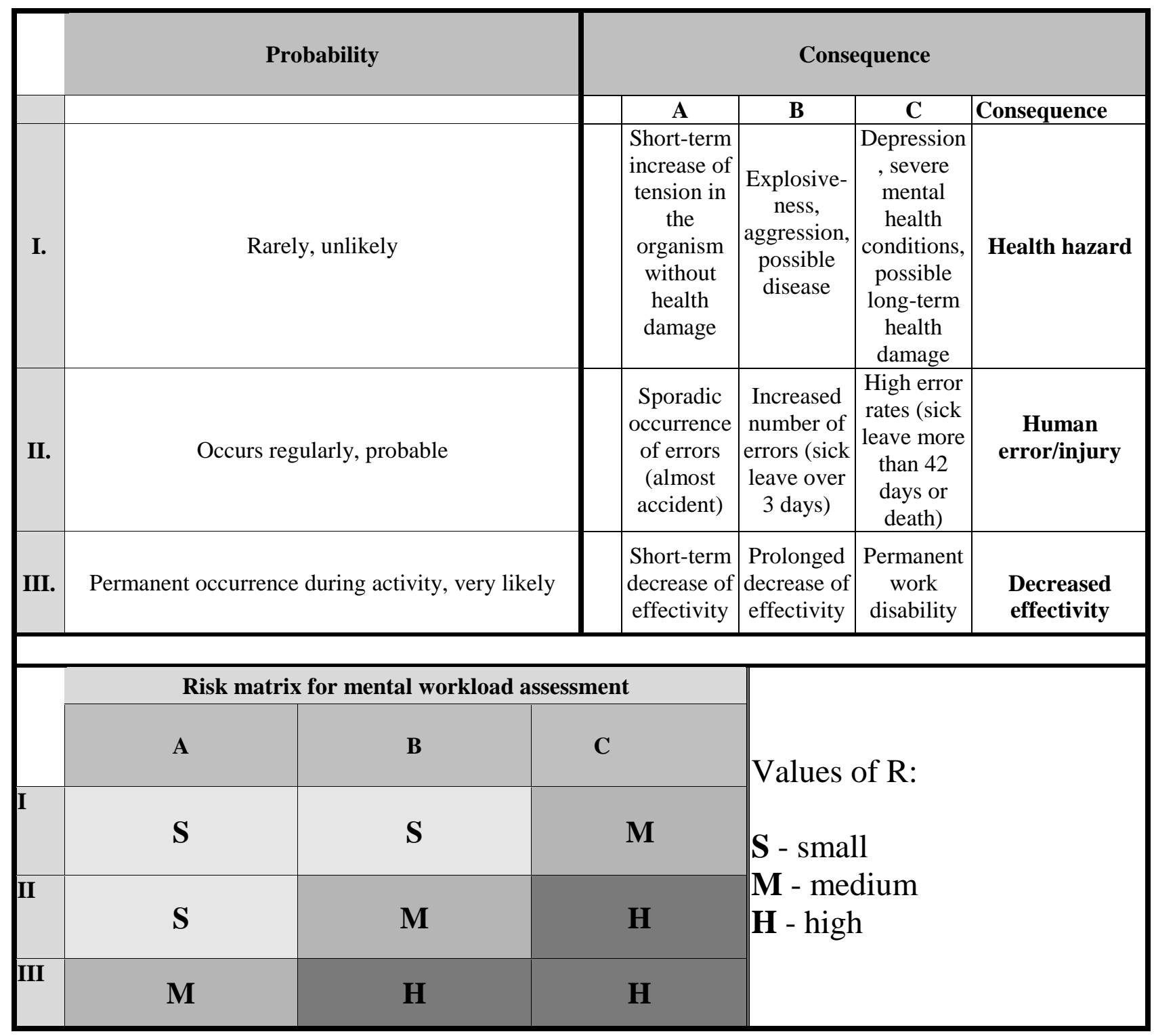

Tab. 2. Matrix for risk assessment of mental workload

\subsection{The proposal of measures to eliminate the stressors, documenting}

To eliminate or reduce the risk arising from hazards it is appropriate to follow these steps:

- If the risk is assessed as high and unacceptable, risk reduction measures must be implemented immediately,

- If the risk is medium and considered to be acceptable, it is recommended to plan measures to reduce the level of risk,

- If the risk is small and assessed as acceptable, it is necessary to make sure that it will remain on the same low level, therefore it must be communicated.

Assessment of psychosocial risks at work can be entered into the form (Tab. 3). 
Pacaiova, H. \& Balazikova, M.: Assessment of Psychosocial Risks at Work

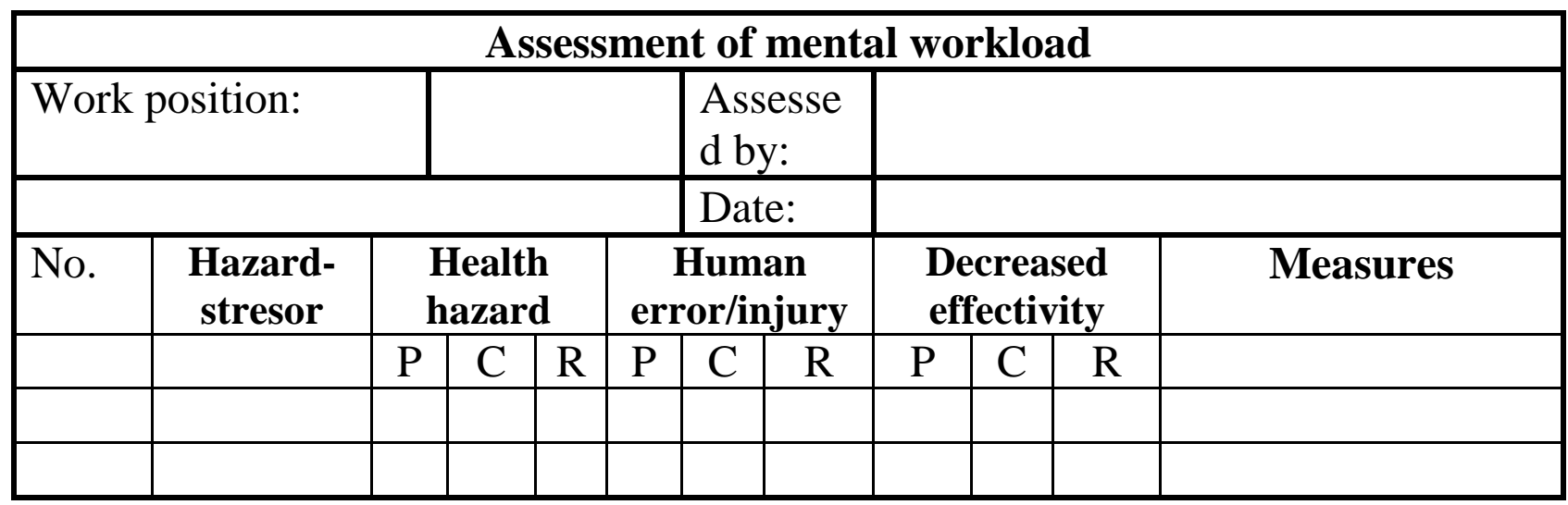

Tab. 3. Form for the assessment of psychosocial risks at work

4. Case study - Practical application of the work stress assessment using the proposed algorithm for the assessment of psychosocial risksfor employee working with people over the counter

Assessment of the work stress has been performed for one counter employee. In Tab. 4. there are some of the stressors identified by employee as hazard.

\begin{tabular}{|l|l|c|c|c|}
\hline No. & HAZARD: Stress at work & Yes & $\begin{array}{c}\text { Some- } \\
\text { times }\end{array}$ & No \\
\hline III. & Organization of work & & & \\
\hline 32. & $\begin{array}{l}\text { Do employees usually work under high time } \\
\text { pressure? }\end{array}$ & $\bullet$ & o & o \\
\hline 33. & Is the workload usually very high? & o & $\bullet$ & o \\
\hline 34. & Does rush work occur often in the workplace? & $\bullet$ & o & o \\
\hline
\end{tabular}

Tab. 4. Checklist with identified stressors

Based on the risk matrix (Tab. 2.) risk assessment was carried out (Tab. 5.) and proposed measures for its elimination.

\begin{tabular}{|c|c|c|c|c|c|c|c|c|c|c|c|}
\hline \multirow{3}{*}{ No. } & \multirow{3}{*}{$\begin{array}{l}\text { Identified } \\
\text { hazard- } \\
\text { stressor }\end{array}$} & \multicolumn{9}{|c|}{ Calculation of risk } & \multirow{3}{*}{ Measures } \\
\hline & & \multicolumn{3}{|c|}{$\begin{array}{l}\text { Health } \\
\text { hazards }\end{array}$} & \multicolumn{3}{|c|}{$\begin{array}{c}\text { Human } \\
\text { error/injury }\end{array}$} & \multicolumn{3}{|c|}{$\begin{array}{l}\text { Decreased } \\
\text { effectivity }\end{array}$} & \\
\hline & & $\mathrm{P}$ & $\mathrm{C}$ & $\bar{R}$ & $\mathrm{P}$ & $\mathrm{C}$ & $\mathrm{R}$ & $\mathrm{P}$ & $\mathrm{C}$ & $\mathrm{R}$ & \\
\hline 1. & Rush work & II & A & $\mathrm{S}$ & II & B & $\mathrm{M}$ & I & A & $\mathrm{S}$ & $\begin{array}{l}\text { Clear determination of tasks } \\
\text { and responsibilities. }\end{array}$ \\
\hline 2. & $\begin{array}{c}\text { High } \\
\text { workload }\end{array}$ & I & $\mathrm{A}$ & $\mathrm{S}$ & II & B & M & $\mathrm{I}$ & A & $\mathrm{S}$ & $\begin{array}{l}\text { Hiring new employees and } \\
\text { accommodation of work } \\
\text { schedule to reduce overload. }\end{array}$ \\
\hline
\end{tabular}




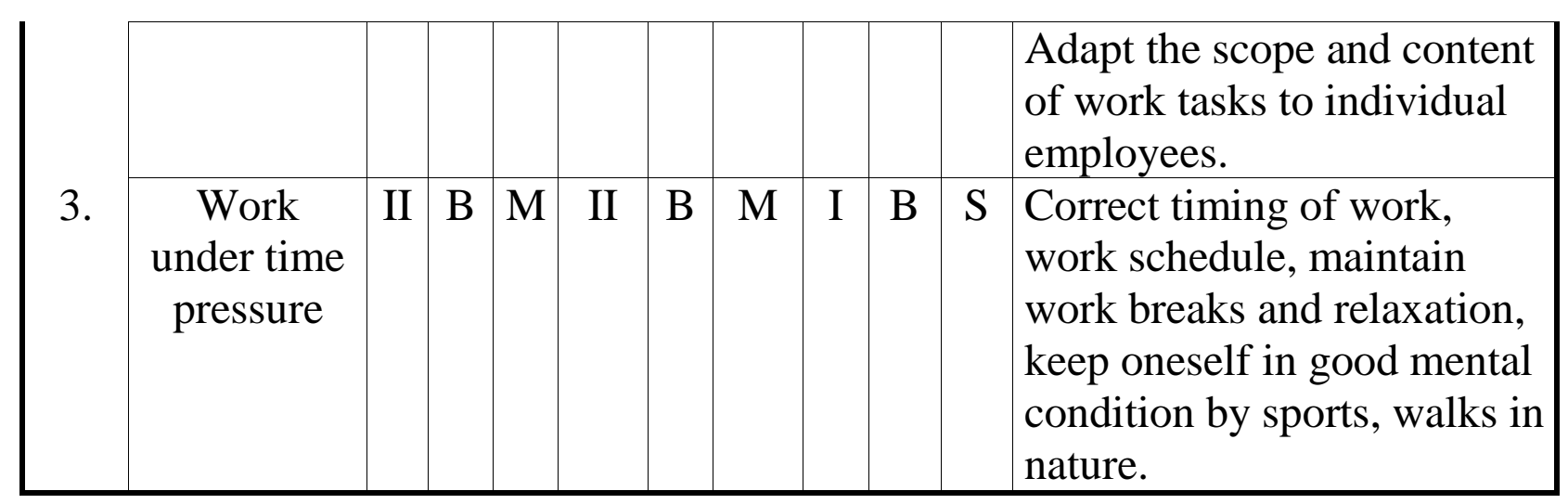

Tab. 5. Risk assessment of identified stressors for counter employee

\section{What can I do to reduce the risks of Psychosocial Factors?}

As with physical risk factors, psychosocial issues are best addressed with full consultation and involvement of the workforce.

Consider the following control measures that can be often be applied to improve the working environment within your workplace:

- reducing the monotony of tasks where appropriate,

- ensuring there are reasonable work load (neither too much or too little) deadlines and demands,

- ensuring good communication and reporting of problems,

- encouraging teamwork,

- monitoring and control shift work or overtime working,

- reducing or monitoring payment systems which work on piece rate,

- providing appropriate training (Management of Health and Safety at Work,2000).

The goal if research was application of developed risk matrix for assessing the psychosocial risk in operation and then a proposal measures to minimize them.

\section{Conclusion}

In all stages of product life cycle and in all processes of the organization, human appears as a basic factor determining the safety, quality and performance. Reliability of the human factor is seen as an integral part of risk assessment. Human reliability assessment is highly complex and unpredictable process that requires perfect knowledge of the system, i.e. facilities, equipment, risk identification, professions and above all, the abilities of individuals (employees). Reliability of human work can be generally characterized as the probability attributed to something or someone, or the probability, that he/she successfully completes the work or the task in given phase of the system operation, within a specified time interval, under specified requirements on the final result.

Human reliability is defined as:

$$
\mathrm{P}_{\mathrm{c}}=\mathrm{P}_{\mathrm{o}} \times \mathrm{P}_{\mathrm{f}} \times \mathrm{P}_{\mathrm{ps}}
$$


Where:

$\mathrm{P}_{\mathrm{o}}$ - the probability of professional (knowledge) level,

$\mathrm{P}_{\mathrm{f}}$ - the probability of physical dispositions,

$\mathrm{P}_{\mathrm{ps}}$ - the probability mental quality properties.

Psychosocial risk assessment must include the full range of human error, from sketching up the formal errors, tension, fatigue even to stress, because human errors are often caused by work stress.

Psychosocial risk is emerging risks, which need attention. The risk is difficult to determine in general (there are no limits of its impact). The future of this research is proposal of methodology of psychosocial risk assessment, consulting experts, such as. psychologists, sociologists and so on.

\section{Acknowledgements}

This contribution is prepared within 7RP called iNTeg Risk no. CP-IP 2133452 and co-founded by Agency for Research and Development under contract No. DO7RP-0019-08

\section{References}

Kul'havý, M.. Zvýšenie výkonnosti zamestnancov minimalizovaním pracovného stresu, dizertačná práca, 2005

Sabolová,S. 2009. Požiadavky na zdravé pracovisko - vplyv stresových faktorov, Diplomová práca

Šolc, M., Sütőová, A. 2009. Effect of stress and psychological overload at work on performance of employees, Kvalita Inovácia Prosperita, Ročník XIII/2- 2009, ISSN 1335-1745

Management of Health and Safety at Work. Management of Health and Safety at Work Regulations 1999. Approved Code of Practice and guidance (L21) (Second Edition) 2000, ISBN 0717624889

Európska agentúra pre bezpečnost' a ochranu zdravia pri práci: Fakty 80 [online]. c2007 [cit 2009-3-6]. http://www.bozpo.sk/public/poradna/fact/fact80_sk.pdf> 